\title{
Podite carrying ciliates dominate the benthic ciliate community in the kelp forest
}

\author{
Ingrid Gismervik*
}

Section of Marine Biology and Limnology, University of Oslo, PO Box 1069 Blindern, 0316 Oslo, Norway

\begin{abstract}
The ciliate fauna on the kelp Laminaria hyperborea and 5 of its epiphytes was sampled in April and August, off the north-west coast of Norway. The lamina of the kelp carried few (old lamina) or no ciliates (new lamina), while podite carrying cyrtophorids of the order Dysteriida prevailed in April on the epiphytes. The highest number of ciliates was found on Ectocarpus sp. (total ciliate number of $20352 \pm 5040$ ciliates $\mathrm{g}^{-1}$ fresh weight, FW), with species of the genus Dysteria $\left(8008 \pm 1928 \mathrm{~g}^{-1} \mathrm{FW}\right)$ and 1 species of the genus Hartmannula (Hartmannula angustipilosa; $8767 \pm$ $5202 \mathrm{~g}^{-1} \mathrm{FW}$ ) being dominant. In August, the abundance of ciliates was greatly reduced on all epiphytes, although more taxa were observed. Aspidisca spp. (4829 $\left.\pm 987 \mathrm{~g}^{-1} \mathrm{FW}\right)$ dominated total numbers $\left(6080 \pm 1118\right.$ ciliates $\left.\mathrm{g}^{-1} \mathrm{FW}\right)$ on Ectocarpus sp. The infraciliature of 7 species from the family Dysteridae, including Agnathodysteria littoralis, Trochilia sigmoides and Dysteria monostyla, is described. The dysterids and $H$. angustipilosa carry a flexible podite by which they attach to the surface. The podite may be the key to success in this wave- and current-exposed environment.
\end{abstract}

KEY WORDS: Benthic ciliates · Dysteria spp. $\cdot$ Cyrtophorids $\cdot$ Kelp forest $\cdot$ Epiphytes $\cdot$ Abundance

\section{INTRODUCTION}

While the importance and function of ciliates in planktonic food webs have received much attention over the last decades (Gismervik et al. 1997, Sherr \& Sherr 2002), the role of ciliates associated to benthic algal communities has been explored to a far lesser extent. Kelp forest communities are highly productive ecosystems (Mann 2000). Along the Norwegian coast, these forests are dominated by the large brown algae Laminaria hyperborea (Gunnerus) Foslie (Kain 1967), which can reach a length of $3.5 \mathrm{~m}$ and an age between 10 and $20 \mathrm{yr}$ (Sjøtun et al. 1995). The kelp consists of a holdfast and a stipe, as well as a lamina which is exchanged every year. The stipe is typically overgrown with annual epiphytic algae, and altogether these plants make up a heterogeneous and seasonally changing habitat for a variety of animals (Christie et al. 1998, Norderhaug et al. 2002). Considering the high production of carbon in the kelp forest, much of which is channelled through the microbial food web by bacteria utilising DOM and POM from ageing plants and debris (Newell \& Lucas 1981, Mann 2000), one should expect protists to be abundant in this system. A few studies have assessed the abundance of ciliates in seaweed communities (Armstrong et al. 1999, Hillebrand et al. 2002), but the contribution of different taxonomic groups as well as their role in the food web remains unexplored. However, the studies performed reveal a range of ciliates with different feeding modes and food preferences (Armstrong et al. 1999, Hillebrand et al. 2002).

This study gives the first data on ciliate taxa and abundance in a kelp forest. Benthic ciliates living on the lamina of Laminaria hyperborea and 5 of its epiphytes were sampled in spring and early autumn. The dominant species were identified using protargol stains. 


\section{MATERIALS AND METHODS}

Algae were collected by scuba divers off the coast of Finnøy $\left(62^{\circ} 50^{\prime} \mathrm{N}\right)$, north-west Norway. The site is semi-exposed to wave action and contains welldeveloped forests of Laminaria hyperborea. The samples were collected at approximately $4 \mathrm{~m}$ depth, put in plastic bags with water, sealed and brought to the surface. Three sub-samples of each algae were taken within $1 \mathrm{~h}$, put in brown bottles, to which 50 to $100 \mathrm{ml}$ water was added, and fixed in $2 \%$ acid Lugol's (some algae seemed to absorb some of the fixative, and the samples were re-fixed within a few weeks). Ciliates were also studied alive under an inverted microscope, with and without epifluorescence. Water temperature was 4 and $15^{\circ} \mathrm{C}$ in April and August 2002, respectively. Salinity in these waters is stable and around $34 \%$.

In the laboratory, bottles with macroalgae suspended in seawater were gently mixed, and 10 or $50 \mathrm{ml}$ was poured in Utermöhl chambers for enumeration under an inverted microscope at $200 \times$ magnification. Small rotifers were also counted in these chambers. Finely branched algae (Ptilota gunneri and Ectocarpus sp.) were washed to remove ciliates that still adhered to the plant, and the wash water was settled in another Utermöhl chamber. Although living Dysteria cells attach to surfaces, it was observed that the cells became detached as soon as fixative was added. Sessile ciliates like peritrichs were not collected using this method. Excess water was removed from the algae, and the algal fresh weight (FW) recorded.

Few ciliates were found in Lugol samples containing the lamina of the kelp. An additional method was used to check the surface of the kelp, to see whether any ciliates were still present on the lamina. Formaldehyde fixed sub-samples of the lamina $\left(3.8 \mathrm{~cm}^{2}\right)$ were sub- merged in DAPI (50 $\mu \mathrm{g} \mathrm{m}^{-1}$ ) for $1 \mathrm{~min}$, gently dipped in $0.1 \mathrm{M}$ Trizma-HCl solution and mounted on a slide with paraffin oil. The samples were checked for ciliates at $400 \times$ magnification under UV illumination.

Species identification was based on protargol stained samples in accordance with the method of Montagnes \& Lynn (1993). The methods of Lee et al. (2000) and Gong et al. (2002) are used for classification and terminology, respectively.

\section{RESULTS AND DISCUSSION}

Five different epiphytes with variable surface properties were collected (Table 1). Ciliate numbers were highest on the finely branched algae; in April more than 20000 ciliates were found on $1 \mathrm{~g}$ FW Ectocarpus sp. (Table 1). Ciliate abundances on the other epiphytes were 1 to 2 orders of magnitude lower (Table 1). Lowest numbers were found for 2 of the leaf-like algae with a smooth surface. In August, ciliate abundance was reduced on Ectocarpus sp. and Ptilota gunneri (Fig. 1). Numbers remained approximately the same in both months for the other algae, but there was a change in dominant taxa (Fig. 1). Members of the genus Dysteria Huxley, 1857 dominated on all epiphytes in April, except on Ectocarpus sp., where the species Hartmannula angustipilosa (Deroux \& Dragesco 1968) of the genus Hartmannula Poche 1913 was dominant, reaching numbers similar to those for Dysteria (Fig. 1). In August, numbers of Dysteria spp. were in the same range as other taxa, and a small $(<20 \mu \mathrm{m})$ relative from the genus Trochilia appeared (Trochilia sigmoides Deroux, 1976). Aspidisca spp. became more important in August, and although dominated by Aspidisca steinii Buddenbrock, 1920 (Song \& Wilbert 1997), a smaller unidentified species

Table 1. List of macroalgal species, period of sampling, mean number of ciliates recorded per gram fresh weight (FW) algae $\pm \mathrm{SD}$ $(\mathrm{n}=3)$, and dominant taxa of ciliates. nd: no data

\begin{tabular}{|c|c|c|c|c|}
\hline Macroalgae & Algae structure & Sampled & Ciliates $\mathrm{g}^{-1} \mathrm{FW}$ & Dominant ciliate taxa \\
\hline $\begin{array}{l}\text { Laminaria hyperborea: } \\
\text { Old lamina without epiphytes } \\
\text { New lamina }\end{array}$ & Leaf-like leathery & $\begin{array}{l}\text { April } \\
\text { April } \\
\text { August }\end{array}$ & & $\begin{array}{l}\text { A few specimens found } \\
\text { No ciliates found on the lamina } \\
\text { No ciliates found on the lamina }\end{array}$ \\
\hline Palmaria palmata & Leaf-like lobed & $\begin{array}{l}\text { April } \\
\text { August }\end{array}$ & $\begin{array}{l}138 \pm 17 \\
136 \pm 39\end{array}$ & $\begin{array}{l}\text { Small Dysteria sp. }(30-35 \mu \mathrm{m}) \\
\text { Aspidisca steinii }\end{array}$ \\
\hline Delesseria sanguinea & Leaf-like smooth & $\begin{array}{l}\text { April } \\
\text { August }\end{array}$ & $\begin{array}{l}170 \pm 178 \\
215 \pm 125\end{array}$ & $\begin{array}{l}\text { Small Dysteria sp. }(30-35 \mu \mathrm{m}) \\
\text { Aspidisca steinii } \\
\text { Species from subclass Stichotricha }\end{array}$ \\
\hline Membranoptera alata & Leaf-like smooth & $\begin{array}{l}\text { April } \\
\text { August }\end{array}$ & $\begin{array}{l}2396 \pm 757 \\
\text { nd }\end{array}$ & $\begin{array}{l}\text { Small Dysteria sp. }(30-35 \mu \mathrm{m}) \\
\text { Not sampled }\end{array}$ \\
\hline Ptilota gunneri & Branched compressed & $\begin{array}{l}\text { April } \\
\text { August }\end{array}$ & $\begin{aligned} 2120 & \pm 1038 \\
331 & \pm 40\end{aligned}$ & $\begin{array}{l}\text { Small Dysteria sp. }(30-35 \mu \mathrm{m}) \\
\text { Aspidisca steinii }\end{array}$ \\
\hline Ectocarpus sp. & $\begin{array}{l}\text { Filamentous finely } \\
\text { branched }\end{array}$ & $\begin{array}{l}\text { April } \\
\text { August }\end{array}$ & $\begin{aligned} 20352 & \pm 5040 \\
6080 & \pm 1118\end{aligned}$ & $\begin{array}{l}\text { Hartmannula angustipilosa } \\
\text { Aspidisca spp. }\end{array}$ \\
\hline
\end{tabular}



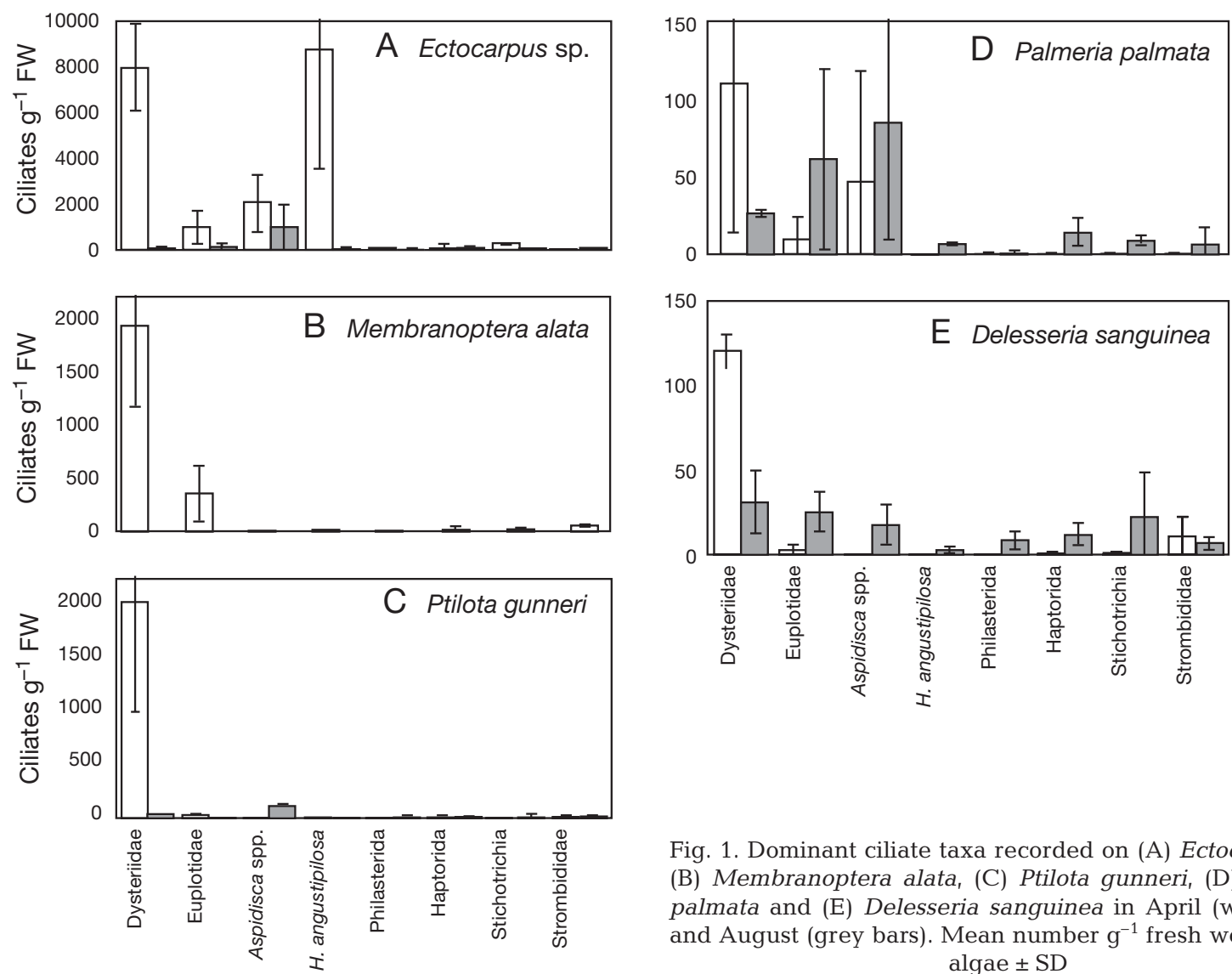

Fig. 1. Dominant ciliate taxa recorded on (A) Ectocarpus sp., (B) Membranoptera alata, (C) Ptilota gunneri, (D) Palmaria palmata and (E) Delesseria sanguinea in April (white bars) and August (grey bars). Mean number $\mathrm{g}^{-1}$ fresh weight (FW) algae $\pm \mathrm{SD}$

was then frequently recorded. Euplotes spp. were always present, but never in high numbers. Common species from the order Haptorida were Dileptus sp., Trachelius sp. and Lacrymaria sp.

In contrast to the high numbers of ciliates found on the epiphytes of the kelp, no ciliates were recorded on the lamina itself in August, while a few were observed on old kelp with epiphytes from April (this kelp was from the previous year) (Table 1). Direct observation of

the lamina under epifluorescence (see 'Materials and methods') confirmed the results from the lugol fixed samples. The surface of the kelp was smooth and protists were only present on the old lamina or where the lamina had been damaged.

At least 6 different species from the genus Dysteria were found (Fig. 2A-D, Table 2). Individuals were assigned to different categories of size and shape. From these counts, combined with the study of pro-

Table 2. Infraciliature of 7 species from the family Dysteriidae. Size measurements (length, height) are of protargol stained specimens, mean $\pm \mathrm{SD} ; \mathrm{n}=$ number of specimens. RvK: right ventral kinety; LK: left equatorial kinety; FvK: frontoventral kinety (sensu

Gong et al. 2002, see also Fig. 2). Numbers in parentheses are number of specimens recorded with clearly visible kineties

\begin{tabular}{|c|c|c|c|c|c|c|c|}
\hline Species & $\begin{array}{l}\text { Cell size } \\
(\mu \mathrm{m})\end{array}$ & $\mathrm{n}$ & RvK & LK & FvK & Habitat & $\begin{array}{l}\text { Position of } \\
\text { cytopharynx }\end{array}$ \\
\hline Trochilia sigmoides & $13.0 \pm 0.9,9.6 \pm 0.9$ & 10 & $2(10)$ & $2-4$ & $2(10)$ & Ectocarpus sp. & Diagonal \\
\hline Agnathodysteria littoralis & $30.7 \pm 3.5,18.6 \pm 1.4$ & 10 & $4(8)$ & $4-5(4)$ & $3(9)$ & $\begin{array}{l}\text { Ptilota gunneri } \\
\text { Ectocarpus sp. } \\
\text { Palmaria palmata }\end{array}$ & $\begin{array}{l}\text { Vertical/ } \\
\text { diagonal }\end{array}$ \\
\hline Slender Dysteria sp. & 33,16 & 1 & 3 & $>4$ & 1 & Ectocarpus sp. & Longitudinal \\
\hline Medium Dysteria sp. 1 & $36.7 \pm 3.7,19.2 \pm 1.8$ & 10 & $4(10)$ & $3-5(4)$ & $1(10)$ & $\begin{array}{l}\text { Ptilota gunneri } \\
\text { Ectocarpus sp. }\end{array}$ & Diagonal \\
\hline Medium Dysteria sp. 2 & $36.7 \pm 5.4,22.5 \pm 3.3$ & 6 & $6-7(5)$ & $4(2)$ & $1(5)$ & Ptilota gunneri & Diagonal \\
\hline Dysteria monostyla & $39.0 \pm 2.8,25.5 \pm 2.7$ & 2 & $4(2)$ & Yes & $2(2)$ & Ectocarpus sp. & Longitudinal \\
\hline Large Dysteria sp. & 84,56 & 1 & 7 & 7 & 3 & Delesseria sanguinea & Longitudinal \\
\hline
\end{tabular}



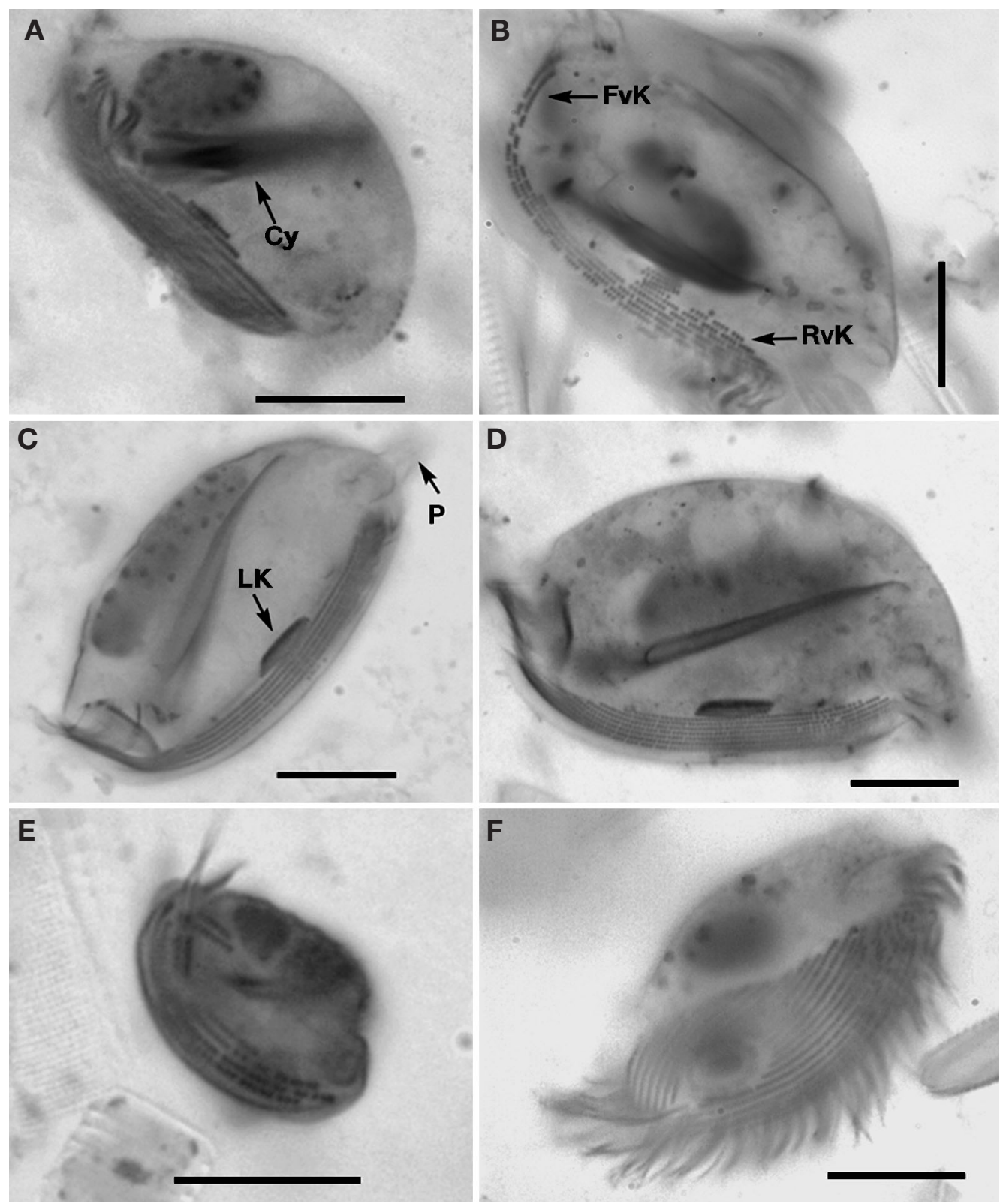

Fig. 2. Protargol stained specimens of (A) Agnathodysteria littoralis, (B) Dysteria monostyla, (C) Dysteria sp. 1, (D) Dysteria sp. 2, (E) Trochilia sigmoides, and (F) Hartmannula angustipilosa. Scale bars $=10 \mu \mathrm{m}$. Cy: cytopharynx; FvK: frontoventral kinety; RvK: right ventral kinety; LK: left equatorial kinety; P: podite

targol stained specimens, it was concluded that Agnathodysteria littoralis Deroux, 1976 dominated by number. To my knowledge, this ciliate has only been reported by Deroux (1976), who collected the species from the brown algae Fucus serratus. It was considered common, but never abundant. It is difficult to say whether this species has been described previously, as the infraciliature of dysterids was not reported in earlier taxonomic works of, e.g., Kahl (1931).

Four other medium sized Dysteria species (37-39 $\mu \mathrm{m}$ long) were frequently recorded while 1 large species (ca. $>80 \mu \mathrm{m}$ ) was rare (Table 2). The species were identified on the basis of their ventral infraciliature, which is highly species specific (Gong et al. 2002), cell size and position of cytopharynx (Table 2). Although about 30 nominal species within the genus Dysteria have been described, the infraciliature is only known for 7 of these (see Gong et al. 2002 and references therein). The most frequently reported species, Dysteria monostyla, is widespread and has been encountered in several regions of the Atlantic Ocean as well as in the Yellow Sea (Stein 1859, Deroux 1965, 
Dragesco \& Dragesco-Kernéis 1986, Gong et al. 2002). The specimens found in this study differ slightly from the previously described forms, as they have 4 rather than 3 right ventral kineties. However, the last kinety of the right ventral kinety is short (Fig. 2), and terminates behind the left equatorial kinety. The species is named $D$. monostyla here, as its other features regarding infraciliature, cytopharynx, size and form are in concert with previous descriptions.

In the Lugol fixed samples, Hartmannula angustipilosa was distinguished by its peculiar shape, as the anterior end clearly protruded from the rest of the oval cell (Fig. 2F). This species also carries a small podite, and attaches to the substrate by a thread like Dysteria spp. The kelp forest is usually situated in exposed areas, subject to strong tidal currents and wave action. The ability of the dysteriids to attach to the substratum by a thread may explain their success in this particular system.

Live observations and Lugol samples revealed high numbers of a small $(<100 \mu \mathrm{m})$ rotifer of the genus Colurella. In April, nearly 8000 specimens were recorded for $1 \mathrm{~g} \mathrm{FW} \mathrm{Ectocarpus} \mathrm{sp.} \mathrm{(data} \mathrm{not} \mathrm{shown),}$ while numbers were low for the other macroalgae $\left(<20\right.$ ind. $\left.\mathrm{g}^{-1} \mathrm{FW}\right)$, as well as for all algae in August $\left(<300\right.$ ind. $\left.\mathrm{g}^{-1} \mathrm{FW}\right)$. With their foot retracted into their lorica, Colurella resemble a dysteriid, both in shape and in size, and care should be taken not to mistake these multi-cellular organisms for ciliates (see Turner 1995). According to Thane-Fenchel (1968) these rotifers feed on diatoms, dinoflagellates and various bacteria. The dysterid ciliates (both Dysteria and Hartmannula) may also exploit single and filamentous bacteria (Fenchel 1987, Gong et al. 2002), and personal observation of dysterids under epifluorescence suggests that they feed on microalgae. Thus, the small rotifers are likely competitors to ciliates, rather than predators. In spring, the surface of the epiphytes was covered with pennate diatoms. These were observed inside protargol stained cells of both strombidiid ciliates and members of Haptorida, suggesting a flow of carbon from primary producers, using the macrophytes as substrate, to ciliates, in addition to a microbial pathway, from macrophyte carbon via bacteria to protozoans.

More taxa were observed in August than in April, although total numbers declined. Despite variable surface properties, and variable abundance of ciliates on the different epiphytes (100 to 6000 ciliates $\mathrm{g}^{-1} \mathrm{FW}$ ), the same number of taxa were recorded on all epiphytes in August. A corresponding pattern has been found for macrofauna associated with various macroalgae (Lippert et al. 2001, Christie et al. 2003). This suggests that factors other than surface properties and habitats may play an important part in increasing numbers of taxa, like increased food diversity. Also, in
August the metazoan community was abundant and diverse compared to the situation in spring, indicating increased predation pressure on ciliates (Christie et al. 2003). An increase in bacterivorous (Aspidisca steinii, Uronema sp.) as well as carnivorous species (Dileptus sp., Lacrymaria sp.) further suggests that both the food and predator regime had changed compared to the situation in spring. Another factor that may explain the increased diversity is that while the spring community is young and newly established after the winter season, the early autumn community has had time to recruit specimens from other plants and areas. Thus, the diversity and abundance of the ciliate community in the kelp forest results from a balance between establishment of habitat, recruitment of species, and changing food availability on the one hand, and predation pressure from a variety of micro-, meio- and macrofauna on the other hand.

Acknowledgements. The effort of the scuba divers $\mathrm{H}$. Christie, K. M. Norderhaug and S. Fredriksen is appreciated. I thank S. Brubak for preparing the protargol stains, and K. Nygaard for discussions on methods. I thank S. Fredriksen and S. Kaartvedt for reading drafts of the manuscript, and W. Eikrem for help with the photos. Valuable comments from 3 anonymous referees are appreciated.

\section{LITERATURE CITED}

Armstrong E, Rogerson A, Leftley JW (1999) The abundance of heterotrophic protists associated with intertidal seaweeds. Estuar Coast Shelf Sci 50:415-424

Christie H, Fredriksen S, Rinde E (1998) Regrowth of kelp and colonization of epiphyte and fauna community after kelp trawling at the coast of Norway. Hydrobiology 375/376: $49-58$

Christie H, Jørgensen NM, Norderhaug KM, Waage-Nielsen E (2003) Species distribution and habitat exploitation of fauna associated with kelp (Laminaria hyperborea) at the Norwegian coast. J Mar Biol Assoc UK 83:687-699

Deroux G (1965) Origine des cinéties antérieures, gauches et buccales dans le génre Dysteria Huxley. CR Acad Sci Paris 2260: 6689-6691

Deroux G (1976) Plan cortical des cyrtophorida III-les structures différenciatrices chez les Dysteriina. Protistologica 12:505-538

Deroux G, Dragesco J (1968) Nouvelles données sur quelques ciliés holotriches cyrtophores a ciliature ventrale. Protistologica 4:365-408

Dragesco J, Dragesco-Kernéis A (1986) Ciliés libres de l'Afrique intertropicale. Faune Tropicale 26:1-559

Fenchel T (1987) Ecology of Protozoa. Springer-Verlag, Berlin

Gismervik I, Andersen T, Vadstein O (1997) Pelagic food webs and eutrophication of coastal waters: impact of grazers on algal communities. Mar Pollut Bull 33:22-35

Gong J, Song W, Warren A (2002) Redescriptions of two marine cyrtophorid ciliates, Dysteria cristata (Gourret and Roeser, 1888) Kahl, 1931 and Dysteria monostyla (Ehrenberg, 1838) Kahl, 1931 (Protozoa, Ciliophora; Cyrtophorida), from China. Eur J Protistol 38:213-222

Hillebrand H, Kahlert M, Haglund AL, Berninger UG, Nagel 
S, Wicham S (2002) Control of microbenthic communities by grazing and nutrient supply. Ecology 83:2205-2219

Kahl A (1931) Urtiere oder Protozoa I: Wimpertiere oder ciliata (Infusoria). Tierwelt Dtl 21:243-259

Kain JM (1967) Populations of Laminaria hyperborea at various latitudes. Helgol Wiss Meeresunters 15:489-499

Lee JJ, Leedale GF, Bradbury P (2000) An illustrated guide to the protozoa. Society of Protozoologists, Lawrence, KS, p 1-689

Lippert H, Iken K, Rachor E, Wiencke C (2001) Macrofauna associated with macroalgae in the Kongsfjord. Polar Biol 24:512-522

Mann K (2000) Ecology of coastal waters: with implications for management. Blackwell Science, Malden, MA

Montagnes DJS, Lynn DH (1993) A quantitative protargol stain (QPS) for ciliates and other protists. In: Kemp PF, Sherr BF, Sherr EB, Cole JJ (eds) Handbook of methods in aquatic microbial ecology. Lewis Publishers, Boca Raton, p 229-240

Newell RC, Lucas MI (1981) The quantitative significance of dissolved and particulate organic matter released during the fragmentation of kelp in coastal waters. Kiel Meeresforsch Sonderh 5:356-369

Editorial responsibility: Fereidoun Rassoulzadegan, Villefranche-sur-Mer, France
Norderhaug KM, Christie H, Rinde E (2002) Colonisation of kelp imitations by epiphyte and holdfast fauna; a study of mobility patterns. Mar Biol 141:965-973

Sherr EB, Sherr BF (2002) Significance of predation by protists in aquatic microbial food webs. Antonie Leeuwenhoek 81:293-308

Sjøtun K, Fredriksen F, Rueness J, Lein TE (1995) Ecological studies of the kelp Laminaria hyperborea (Gunnerus) Foslie in Norway. In: Skjoldal HR, Hopkins C, Erikstad KE, Leinaas HP (eds) Ecology of fjords and coastal waters. Elsevier Science, Amsterdam, p 525-536

Song W, Wilbert N (1997) Morphological investigations on some free living ciliates (Protozoa, Ciliophora) from China Sea with descriptions of a new hypotrichious genus Hemigastrostyla nov. gen. Arch Protistenkd 148:413-444

Stein F (1859) Der Organismus der Infusionsthiere nach eigenen Forschungen in systematischer Reihenfolge bearbeitet. I. Verlag von Wilhelm Engelmann, Leipzig

Thane-Fenchel A (1968) Distribution and ecology of nonplanktonic brackish-water rotifers from Scandinavian waters. Ophelia 5:273-297

Turner PN (1995) Rotifer look-alikes: two species of Colurella are ciliated protozoans. Invertebr Biol 114:202-204

Submitted: December 8, 2003; Accepted: May 24, 2004

Proofs received from author(s): July 27, 2004 